\title{
Sobre a relação entre teoria e práxis em Marx ${ }^{1}$
}

\section{On the relationship between theory and praxis in Marx}

\author{
Rúrion Meloa,b \\ aProfessor, Departamento de Ciência Política, Universidade de São Paulo - USP, São Paulo, SP, Brasil. \\ besquisador, Centro Brasileiro de Análise e Planejamento - CEBRAP, São Paulo, SP, Brasil.
}

Resumo: A relação entre teoria e práxis é um dos mais importantes pressupostos da filosofia de Karl Marx e de seu propósito emancipatório. Mostrarei no presente artigo que a exposição dessa relação encontrada nas obras do "jovem Marx" não era suficiente diante das exigências cada vez maiores de se produzir uma crítica imanente da sociedade capitalista. Minha intenção consiste em sublinhar a centralidade da questão acerca da relação entre teoria e práxis, ressaltando, porém, seus diferentes modos de exposição em alguns momentos da obra de Marx bem como as tensões e dificuldades criadas para a fundamentação de sua teoria. Se nos textos de juventude a relação entre teoria e práxis dependeu do conceito abstrato de "ser genérico", nas obras posteriores de crítica da economia política tal relação ficou reduzida ao modo de exposição da lógica de valorização do capital e à perspectiva de uma crise imanente do capitalismo.

Palavras-chave: Marx, teoria e práxis, emancipação, revolução, teoria crítica, proletariado.

\begin{abstract}
The relationship between theory and practice is one of the major assumptions of Karl Marx's philosophy and its emancipatory purpose. I intend to show in this article that the presentation of that relationship in the works of the "young Marx" was not enough in the face of increasing demands to produce an immanent critique of capitalist society. My intention is to highlight the centrality of the question about the relationship between theory and practice, underlining, however, their different modes of presentation in some moments of Marx's works as well as the tensions and difficulties created for the grounding of his theory. If in the texts of the young period the relationship between theory and praxis depended on the abstract concept of "generic being", in the later works of a critique of political economy that relationship has been reduced to the mode of presentation of the logic of capital's valorization and to the perspective of an immanent crisis of capitalism.
\end{abstract}

Keywords: Marx, theory and praxis, emancipation, revolution, critical theory, proletariat.

\footnotetext{
${ }^{1}$ A primeira versão do presente texto foi apresentada em uma conferência na "III Semana da Graduação em Filosofia: Filosofia Política" da UFSCar, no dia 24 de novembro de 2011. Para a versão aqui publicada, foram feitas modificações textuais e atualizações de parte das referências bibliográficas. Pelo convite que me foi feito na ocasião da conferência, agradeço principalmente a Marisa Lopes e a Carlos Eduardo de Oliveira.
} 


\section{Introdução}

Quem se empenha seriamente em compreender os diferentes momentos da obra de Karl Marx nota as dificuldades de se fundamentar adequadamente uma teoria crítica da sociedade. Temos muito a aprender com os caminhos errantes que Marx precisou percorrer para superar uma série de problemas teóricos e práticos, menos preocupado com a integralidade de sistemas filosóficos do que com uma teoria capaz de apreender de maneira adequada os diagnósticos a respeito da sociedade capitalista, uma teoria atenta para seu próprio enraizamento histórico e social. Por isso, as constantes modificações que abarcam o conjunto de sua obra evidenciam antes a coerência de uma teoria que é crítica em relação aos seus próprios pressupostos e não titubeia em se pôr à prova. Pois Marx precisou ser radicalmente crítico consigo mesmo para, ao longo de mudanças significativas, encontrar uma exposição adequada aos propósitos práticos de sua teoria.

É preciso acrescentar que estamos falando aqui de um esforço de fundamentação muito particular, concernente ao modo peculiar com que Marx fez teoria crítica. Isso implicou, primeiramente, superar o referencial do "idealismo" da filosofia de Hegel (e dos jovens hegelianos) em favor de uma abordagem "materialista", ou seja, em direção a uma teoria crítica da sociedade fundamentada de maneira imanente (consolidada, de acordo com o percurso de sua obra, desde uma insuficiente antropologia filosófica apoiada em Ludwig Feuerbach até chegar ao quadro de uma crítica da economia política). Além disso, Marx nunca pretendeu reduzir sua crítica a especulações puramente teóricas, voltando-se antes para a dimensão da práxis social. A relação entre teoria e práxis é pressuposto fundamental para a compreensão do seu propósito crítico e marca definitivamente o horizonte emancipatório almejado por sua teoria.

Contudo, nem sempre estas duas dimensões puderam ser levadas a cabo conjuntamente. Procurarei indicar, com um breve sobrevoo por algumas de suas principais formulações, que a exposição encontrada por Marx em suas obras de "juventude", ainda que apresentasse uma solução estimulante para a relação entre teoria e práxis, não era suficiente diante das exigências cada vez maiores de se produzir uma crítica imanente da sociedade capitalista. Minha intenção consiste em sublinhar a centralidade da questão acerca da relação entre teoria e práxis, ressaltando, porém, seus diferentes modos de exposição em alguns momentos da obra de Marx bem como as tensões e dificuldades criadas para a fundamentação de sua teoria ${ }^{2}$.

\section{"Ser genérico" como fundamento da crítica}

Os textos que geralmente atribuímos ao "jovem Marx" certamente não poderiam deixar de ser considerados críticos ${ }^{3}$. São "críticos" tanto quanto seus textos posteriores elaborados como crítica da economia política. No entanto, quando investigamos

\footnotetext{
2 Sigo neste ponto especialmente Löwy (2002); Habermas (2013); e Cohen (1982). Considerando a brevidade necessária da exposição feita aqui, sobretudo no que diz respeito à obra madura de Marx, cf. minha tentativa de aprofundar semelhante reflexão em Melo (2013a), principalmente a primeira parte.

${ }^{3}$ Há uma vasta discussão a respeito da periodicidade ou organização mais adequada do vasto conjunto da obra de Marx. Para simplificar, estou assumindo pelo menos quatro momentos: 1) "jovem Marx" (de 1842 a 1844, apontando de forma mais ou menos diferente o fundamento "feuerbachiano" de sua crítica no período), 2) "materialismo histórico" (1845, basicamente A ideologia alemã, com reflexo pontual no prefácio de Para $a$ crítica da economia política, de 1859), 3) "crítica da economia política" (concentrados nas décadas de 1850 e 1860, destacando evidentemente O capital e os Grundrisse), 4) "textos histórico-políticos" (em especial o peculiar modo de exposição crítica de O 18 Brumário de Louis Bonaparte). Cf. também Löwy, op. cit; Giannotti (1966); Brudney (1998); Hartmann (1970); Meyer (1973).
} 
qual é o ponto de vista a partir do qual Marx fundamenta teoricamente sua crítica naquele período, salta à vista diferenças muito importantes em relação à obra tardia.

O referencial teórico mais importante de Marx naquele período estava atrelado à filosofia de Hegel e à discussão levada a cabo pelos "jovens hegelianos". Junto com estes, Marx procurou "superar" o suposto idealismo atribuído à filosofia hegeliana não apenas em relação a problemas lógico-metodológicos de fundamentação, mas principalmente no que diz respeito à dificuldade em manter o referencial hegeliano como uma teoria passível de ser utilizada criticamente. A peculiaridade do movimento "crítico" reivindicado pelos jovens hegelianos reside, de início, na centralidade assumida pela crítica da religião. O pressuposto de toda nova atitude crítica significava antes de tudo fazer crítica da religião e da teologia em geral. E era precisamente pela crítica da religião que tanto a filosofia moderna (Hegel) quanto as condições sociais modernas de existência poderiam ser criticamente discernidas.

No entanto, diferentemente da discussão do período, Marx foi inovador dentre os jovens hegelianos. Pois para ele a crítica da religião já não era mais suficiente como pressuposto de toda a crítica. Fazer uma teoria com propósito crítico implicava agora olhar para a realidade jurídica e política de seu tempo. Como ele mesmo constatou em

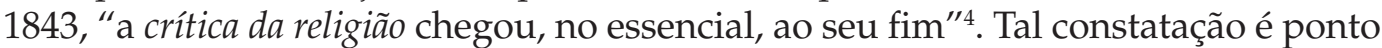
de partida de todos os seus textos a partir de 1842, colocando no centro a crítica do Estado de direito (a centralidade do direito e da política se altera somente na sua primeira aproximação da economia política a partir dos Manuscritos econômico-filosóficos de 1844). ${ }^{5}$ Portanto, só teremos acesso privilegiado ao diagnóstico do tempo presente caso nos voltemos ao Estado de direito e às suas configurações políticas existentes na modernidade. As consequências dessa mudança de enfoque são extremamente ricas, uma vez que definirão as novas tarefas de uma filosofia com pretensões críticas: "Inicialmente, é tarefa da filosofia, que está a serviço da história, e após a forma sagrada da autoalienação humana ter sido desmascarada, desmascarar a autoalienação em suas formas não sagradas. Com isto, a crítica do céu se transforma em crítica da terra, a crítica da religião em crítica do direito, a crítica da teologia em crítica da política"6.

É preciso sublinhar que, apesar da mudança de perspectiva operada na passagem da crítica da religião e da filosofia especulativa para a crítica do direito e da política, o fundamento teórico de tal atitude crítica se manteve preso ao quadro jovem hegeliano. Mais precisamente, Marx se manteve fortemente devedor do modo de operar a filosofia crítica empreendido especialmente por Ludwig Feuerbach ${ }^{7}$. Lançando mão do método da inversão dialética (invertendo a ordem entre sujeito e predicado), Feuerbach criticou a religião por não fazer do homem a verdade da religião. Ao estabelecer a essência antropológica (e, portanto, verdadeira) da religião, Feuerbach criticou a religião como forma de alienação do homem, por produzir uma consciência invertida do mundo, transportando a essência do homem, na qualidade de ser genérico [Gattungswesen], para fora de si. Pois o homem não é predicado de Deus. Sendo sempre objeto para si mesmo, o homem projeta em Deus todos os seus próprios predicados ${ }^{8}$. Mas, ao se objetivar mediante a religião, o homem passa a

\footnotetext{
${ }^{4}$ Marx (1961c, p. 378).

${ }^{5}$ Embora o ponto de vista da crítica da política e do direito se mantenha no período de 1842 a 1844, nem todas as nuances teóricas são as mesmas. Destaco aqui em nota de rodapé o empreendimento de uma sistemática crítica à filosofia do direito de Hegel, sobretudo quando esta assume a perspectiva de uma "democracia radical" em Marx (1961a). Dada a peculiaridade da fundamentação teórica e da abordagem política do texto, optei por não abordá-lo no presente artigo.

${ }^{6}$ Marx, op. cit., p. 379

${ }^{7}$ Cf. Feuerbach, 2007, p. 35 et seq.

8 "A consciência de Deus é a consciência que o homem tem de si mesmo, o conhecimento de Deus o conhecimento que o homem tem de si mesmo" FEUERBACH, op. cit., p. 44.
} 
se desconhecer, alienando sua essência antropológica originária. A tarefa crítica da filosofia feuerbachiana consiste em desmascarar o mundo invertido pela religião e reestabelecer para o homem seu lugar de direito.

Também o jovem Marx interpretará o homem como ser genérico, ainda que ensaie um distanciamento em relação a Feurbach na medida em que se preocupará cada vez mais com a historicidade da natureza humana. E, conforme mencionado, o método da inversão feuerbachiana não será mais aplicado à crítica da religião, mas à tarefa de formular uma crítica da política e do direito. Portanto, Marx percebe que poderá empregar de maneira frutífera a inversão feurbachiana e redirecionar a atitude crítica da teoria para a realidade histórica e social, mantendo o mesmo ponto de vista crítico-normativo já encontrado por Feuerbach: o do ser genérico.

Em Sobre a questão judaica, publicado em 1843 nos Deutsche-Franzözische Jahrbücher, Marx lança mão do método da inversão ao analisar a controversa questão sobre a emancipação política dos judeus. Encontramos neste texto uma versão explícita da teoria crítica com propósito emancipatório. Mas o tema concernente à emancipação política, localizado no quadro das conquistas da Revolução Francesa, mostrar-se-á insuficiente tendo em vista o mencionado propósito emancipatório que preocupa Marx. Mesmo que a liberdade política e os direitos universais do homem tenham marcado um estágio crucial na superação da dominação feudal e absolutista, não teríamos alcançado ainda, segundo Marx, a verdadeira emancipação humana. Era tarefa da crítica, assim, mostrar as limitações da situação pós-revolucionária vigente. Vejamos mais de perto.

A separação entre política secular e religião, consolidada na revolução de 1789, na verdade apenas separara o homem em duas pessoas distintas e contraditórias, dividido entre o bourgeois e o citoyen ${ }^{9}$. Quando assume o papel de cidadão, o homem recebe um estatuto universal e abstrato a título de membro da comunidade política; no papel de burguês, reduz seu comportamento concreto aos interesses e necessidades egoístas dos indivíduos. No primeiro caso, a pretendida universalidade deve ser satisfeita no quadro do Estado de direito (atribuindo ao cidadão o papel de destinatário de direitos universais iguais); no segundo, traz à tona a base social real em que se ancora o discurso político-jurídico universalista, determinando a vida concreta dos indivíduos na esfera de satisfação de interesses e necessidades materiais própria da sociedade civil burguesa.

Portanto, Marx critica a parcialidade da emancipação política (sem deixar de reconhecer certos avanços $)^{10}$ pelo fato de ela encobrir a base social real que tratou de garantir. De um lado, a vida na comunidade política se mostra fictícia e contraditória em relação à vida na sociedade civil burguesa; de outro, a revolução política acabou se mostrando como um meio para os fins da vida burguesa, a serviço não do cidadão como membro de uma comunidade genérica, mas do burguês egoísta. Os direitos do homem e as liberdades básicas dos cidadãos, que foram politicamente conquistados, asseguram, na verdade, os fundamentos econômicos da sociedade civil burguesa (o dinheiro, o comércio, a propriedade privada). Ou seja, o Estado, que deveria ter incorporado a real universalidade da vida social, tratou somente de corroborar de modo parcial os interesses dominantes da sociedade civil burguesa.

Mas o que está permitindo a Marx fundamentar sua crítica contra o falso universalismo do Estado e contra o egoísmo da sociedade civil burguesa? Fica evidente neste texto de 1843 que tanto a alienação política quanto o atomismo burguês colocam em oposição a existência egoísta (homem privado) e o ser genérico dos homens. Trata-se de uma

\footnotetext{
${ }^{9}$ Cf. Marx, 1961b, p. 354 et seq.

10“A emancipação política é, contudo, um grande progresso; ela certamente não é a última forma da emancipação humana em geral, mas é a última forma da emancipação humana dentro da ordem mundial vigente até aqui". Idem, 1961b, p. 356.
} 
contradição inerente à esfera da própria sociedade civil burguesa, mas que precisa ser suprimida pela perspectiva da emancipação humana. $O$ texto opõe abertamente então o egoísmo burguês (garantido pela emancipação política) e uma emancipação conduzida do ponto de vista da totalidade genérica do homem (que só se realizará na qualidade de emancipação social):

Apenas quando o homem individual real tiver recuperado em si o cidadão abstrato e, na qualidade de homem individual na sua vida empírica, no seu trabalho individual, nas suas relações individuais, tiver se tornado ser genérico, apenas quando o homem tiver reconhecido e organizado suas 'force propres' como forças sociais e, por conseguinte, não mais separar de si mesmo a força social na forma da força política, somente então a emancipação humana será realizada ${ }^{11}$.

Logo, a emancipação enquanto tal não pode ser meramente política já que ela apenas garante juridicamente o status de membro da sociedade civil burguesa, o indivíduo egoísta e independente, sem tocar na cisão do homem que precisa ser suprimida. Pelo contrário, toda emancipação, afirma Marx, deve reconduzir ao "próprio homem"12, de modo que passa a ser necessário ampliar o vocabulário da emancipação política em direção à emancipação social.

No entanto, salta aos olhos o fato de que, em Sobre a questão judaica, à emancipação social falta justamente o elemento efetivamente "social". Conforme notou Michel Löwy, op. cit., p. 98,

Marx não destina a tarefa da emancipação humana a nenhuma classe social concreta; o proletariado está ausente, por toda parte trata-se apenas do 'homem', dos 'homens' ${ }^{13}$.

Isso significa que o horizonte da emancipação social está completamente assentado em uma perspectiva meramente filosófica, ainda que antropologicamente fundamentada. A totalidade efetiva pressuposta pelo "social" (e ausente na universalidade abstrata da comunidade política) replica antes a essência genérica humana. Além disso, evidencia que o ponto de vista crítico assumido não precisa considerar algum tipo determinado de práxis social ou política, pois basta aplicar a inversão feuerbachiana ao conceito de sociedade civil burguesa para verificar que o egoísmo deturpa a essência genérica e originária do homem. Ou, dito de outro modo, é possível criticar o egoísmo burguês (e toda a alienação política do qual depende) fundamentando tal crítica no conceito teoricamente construído de ser genérico.

Se em 1843 o argumento da emancipação humana dependia exclusivamente do ponto de vista do ser genérico, no início de 1844, no conhecido artigo "Crítica da filosofia do direito de Hegel. Introdução", surge pela primeira vez no texto de Marx a figura do "proletariado". Contudo, dois pontos são importantes em relação a este texto específico. Em primeiro lugar, o ponto de vista crítico continuará fundamentado no ser genérico do homem. Em segundo lugar, também o enfoque antropológico permitirá superar as limitações da filosofia idealista, mas agora atrelado finalmente à dimensão da práxis humana ${ }^{14}$. No limite, o proletariado entra em cena para corroborar as novas tarefas da filosofia crítica, as quais implicam colocar em primeiro plano a

\footnotetext{
${ }^{11}$ Idem, 1961b, p. 370.

${ }^{12}$ Ibidem, p. 370.

${ }^{13}$ Löwy, op. cit., p. 98.

${ }^{14}$ Como pano de fundo se encontra também a discussão a respeito da miséria alemã. “Da mesma maneira que os povos antigos viveram sua pré-história na imaginação, na mitologia, também nós alemães vivemos nossa pós-história no pensamento, na filosofia. Nós somos contemporâneos filosóficos do presente, sem sermos seus contemporâneos históricos. A filosofia alemã é o prolongamento ideal da história alemã. [...] O que para os povos desenvolvidos é uma ruptura prática diante das condições modernas do Estado, na Alemanha, onde estas mesmas condições ainda não existem, trata-se inicialmente de uma ruptura crítica em relação à reflexão filosófica dessas circunstâncias". Marx, op. cit., p. 383.
} 
essência humana (radicalizando a ideia de que o homem é a raiz do próprio homem) e orientar em termos práticos aquelas suas pretensões críticas formuladas de maneira meramente teórica. Por conseguinte, só conseguiríamos dar continuidade às tarefas da crítica caso a filosofia fosse suprimida, isto é, realizada mediante a atividade prática dos homens.

Nesse sentido, se o intuito de Marx consiste em suprimir a "ficção teórica" levada a cabo pela filosofia, presa a uma dimensão meramente especulativa acerca do direito e do Estado, o referencial antropológico feuerbachiano será crucial para tal propósito. Pois a superação efetiva da filosofia implica voltar a considerar sua verdade no homem real. Porém, diferentemente do que ocorreu em Sobre a questão judaica, agora Marx remete diretamente para um vínculo estreito entre teoria e práxis, já que o esforço crítico contra a filosofia especulativa do direito não se limita a uma atividade unicamente teórica, mas só pode ser consumada na qualidade de atividade prática: a tarefa da crítica, compreendida simultaneamente como realização e, por conseguinte, supressão da filosofia, remete, sobretudo, à práxis ${ }^{15}$.

Daqui em diante, toda a crítica deverá pressupor uma mediação da teoria com a práxis. A teoria crítica adequada não cumprirá suas tarefas sem a práxis humana. Por isso as recorrentes imagens mostrando a necessidade da relação entre o caráter especulativo da teoria (a cabeça, o lado alemão, as armas da crítica) e a atividade prática dos homens (o coração, o lado francês, a crítica das armas):

A arma da crítica não pode substituir a crítica das armas, o poder material tem de ser derrubado pelo poder material, mas a teoria também se torna poder material tão logo atinge as massas. A teoria é capaz de atingir as massas tão logo se demonstra ad hominem, e ela se demonstra ad hominem tão logo se torna radical. Ser radical é agarrar as coisas pela raiz. Mas, para os homens, a raiz é o próprio homem ${ }^{16}$.

Convém sublinhar, contudo, a centralidade da teoria (quase um primado, por assim dizer) diante da práxis. A filosofia ainda é necessária a título de "arma intelectual" imprescindível para as tarefas atuais da crítica, descobrindo no proletariado tão somente as "armas materiais". Marx é enfático quanto a este ponto:

A única libertação praticamente possível da Alemanha é a libertação do ponto de vista da teoria, a qual declara o homem como ser supremo do homem [...] A emancipação do alemão é a emancipação do homem. A cabeça desta emancipação é a filosofia, seu coração é o proletariado. A filosofia não pode se realizar sem a supressão do proletariado, o proletariado não pode se suprimir sem a realização da filosofia ${ }^{17}$.

O proletariado precisa deixar de ser proletariado para restituir justamente sua essência genérica. Na qualidade de proletariado, o homem se realiza socialmente de modo parcial. Mas sua ação revolucionária poderá efetivar historicamente aquilo que a própria filosofia estabeleceu como sua verdade (mais uma vez, a do ser genérico). Ou seja, a filosofia encontra no proletariado a classe universal que usará suas armas materiais para realizar as tarefas já discernidas pela arma da crítica. O proletariado é assim "atingido" de maneira passiva pelo propósito emancipatório que foi gerado a partir da cabeça do filósofo. Falta à alcançada mediação entre teria e práxis um movimento de autodeterminação social produzido substantivamente de dentro da situação real do proletariado, o qual deveria tomar consciência de forma autônoma da necessidade de levar adiante um processo político emancipatório. Em suma, sua

\footnotetext{
${ }^{15}$ “A crítica da filosofia especulativa do direito não se desenvolve em si mesma, mas em tarefas para cuja solução há apenas um meio: a práxis". Idem, 1961b, p. 385.

${ }^{16}$ Ibidem.

${ }^{17}$ Ibidem, p. 391.
} 
emancipação não deveria ser a realização da filosofia, mas significar antes a realização de sua autoemancipação ${ }^{18}$.

No mesmo ano, em 1844, os famosos Manuscritos econômico-filosóficos representam uma mudança decisiva na abordagem tratada até aqui. De um lado, Marx faz sua primeira incursão nas questões de economia política. Além disso, procura mais uma vez escapar das formulações abstratas do hegelianismo, tirando o foco da teoria crítica de operações especulativas e redirecionando-o para atividades materiais. Com tal propósito, entra em cena o conceito de trabalho. Porém, de outro lado, toda a novidade operada pela tentativa de uma crítica da economia política fundada no trabalho (considerando aí a crítica da propriedade privada, da divisão de trabalho e do fenômeno principal do trabalho alienado) ainda não é determinada imanentemente pelo modo de produção capitalista. Em vez de fundamentar seu ponto de vista crítico de dentro das próprias relações econômicas objetivadas no sistema capitalista, ainda está operando nos Manuscritos de 1844 o método da inversão erigido sob o pano de fundo do conceito feuerbachiano de ser genérico ${ }^{19}$.

Para criticar a alienação sob as condições capitalistas, Marx mostra de que maneira o capitalismo gerou uma cisão drástica entre propriedade privada e aquilo que essencialmente deveria ser considerado um tipo de propriedade verdadeiramente humana. Quando olhamos sob o crivo do trabalho assalariado, vemos a não realização de uma atividade essencial e universal do homem (o trabalho), constitutiva da totalidade de sua vida produtiva (na sua relação simbiótica com a natureza e comunitária com os outros homens). O trabalho é a atividade mais vital do homem na qualidade de ser genérico, uma práxis de autorrealização que combina a expressão da vida produtiva com a objetivação da vida genérica do homem: "Precisamente na elaboração do mundo objetivo o homem o homem se confirma de início efetivamente como um ser genérico. Esta produção é sua vida genérica operativa. Por meio dela a natureza aparece como sua obra e sua efetividade. O objeto do trabalho é, portanto, a objetivação da vida genérica do homem [...] Com isso, na medida em que o trabalho alienado [entfremdente Arbeit] arranca do homem o objeto de sua produção, arranca-lhe sua vida genérica, sua objetividade genérica efetiva" ${ }^{20}$. Concebido desta forma, o núcleo crítico-normativo do trabalho não é conceitualmente interpretado a título de categoria verdadeiramente histórica, uma vez que está atrelado tão somente aos pressupostos antropológicos de uma presumida sociabilidade primitiva. A realidade capitalista cria uma cisão na totalidade genérica discernida filosoficamente, totalidade que prescinde de uma gênese histórico-social efetiva.

Fica evidente então que, nos Manuscritos, o fundamento da crítica depende de uma concepção filosófica de ser genérico, ou seja, de um critério externo à própria realidade econômica criticada. O jovem Marx não consegue assim apoiar sua crítica em uma contradição imanente, mas apenas na contradição entre o modo de organização econômica da sociedade e a essência humana abstrata. Até aqui a noção de práxis ainda está presa, de certo modo, a Feuerbach, pelo menos em sua função crítica, já que é medida em relação ao critério de homem em geral nos termos da antropologia filosófica. Como lembra corretamente Giannotti, o conceito de práxis do jovem Marx

\footnotetext{
${ }^{18}$ Algo semelhante ocorrerá na solução de A sagrada família para a relação entre teoria e práxis. Mas neste livro, publicado em 1844 junto com Friedrich Engels, Marx atribui um papel ainda maior à teoria. Pois embora se volte contra a superioridade meramente filosófica da "crítica crítica" avessa às massas (atitude de Bruno Bauer, por exemplo, que chega quase a evitar toda relação da teoria com a práxis), de acordo com Marx, à teoria cabe fazer uma mediação adequada diante de uma massa não plenamente capaz de incorporar as tarefas práticas da crítica. Cf. Engels e Marx (1957). Concordo com Löwy que A sagrada família "é uma etapa da evolução teórica de Marx, etapa necessária, que representa a reação radical à etapa neo-hegeliana anterior, mas que permanece parcial, 'metafísica', porque ainda incapaz de restabelecer a unidade não mística entre o 'coração' e a 'cabeça'". Löwy, op. cit., p. 161.

${ }^{19}$ Cf. principalmente Marx, 1990b, p. 514 et seq.

${ }^{20}$ Idem, p. 517.
} 
ainda é muito dependente da concepção feuerbachiana de "conversão ao gênero, a apreensão e realização dos predicados da essência". ${ }^{21}$ Se tal práxis humana mostra o papel secundário da economia política na construção deste conceito antes filosófico de trabalho, isso explica também a circunstância de, neste modelo crítico fundado no trabalho alienado, o proletariado não cumprir papel ativo algum na superação das condições capitalistas. Antes de superar o referencial feuerbachiano, não haverá ainda uma teoria da revolução baseada de fato na práxis política e histórica do próprio proletariado.

\section{Teoria e práxis? Breve comentário acerca do materialismo histórico e da crítica da economia política}

Conforme procuramos apontar, o conceito de ser genérico estaria presente nas obras do jovem Marx como fundamento do ponto de vista crítico de sua teoria. Isso significa também que a referência a Feuerbach assegurava uma mediação mais ou menos adequada entre teoria e práxis. Neste quadro, o custo disso é que tal mediação, crucial para a atitude crítica, ainda era, a despeito de sua pretensão histórico-social, exclusivamente filosófica e abstrata. Marx só poderá elaborar uma crítica imanente do sistema capitalista quando se distanciar de Feuerbach e se embrenhar nos pressupostos materialistas de uma crítica da economia política, levando adiante "a recusa intransigente de fundar a crítica histórico-econômica numa essência genérica do homem, isto é, a negação de toda antropologia fundante" 22.

A ruptura com Feuerbach é marcada por dois textos de 1845, "Teses sobre Feuerbach" e A ideologia alemã, este escrito junto com Engels. Embora no primeiro seja evidente a insistência de Marx em assinalar radicalmente a importância da práxis (da "atividade prático-crítica" e "revolucionária") contra a concepção de atividade humana sensível, advogada por Feuerbach ${ }^{23}$, é apenas no segundo que vemos a grande novidade decorrente da perspectiva histórico-materialista. Ao introduzir o conceito de modo de produção, Marx já não precisa mais pressupor a totalidade do gênero, concebendo a ação social de dentro da história e de suas diversas formas e sistemas produtivos. A totalidade só existirá como uma totalização que emerge da própria história. Com isso, é possível deslocar noções abstratas como a de ser genérico para os modos de produção e seus períodos dados economicamente, abrindo a possibilidade de pensar a práxis humana não mais como objetivação de um sujeito constituinte, mas a partir de processos sociais objetivamente estruturados.

O tom metodológico de $A$ ideologia alemã é apologético quanto a abordagens científicas e empíricas em detrimento das filosóficas e especulativas. Pois não é somente a entrada definitiva da perspectiva da luta de classes que marca este texto de 1845, mas a tomada de consciência de Marx de que o materialismo histórico deveria agora resolver o problema das condições imanentes de fundamentação da teoria. É por esta razão que a mediação de teoria e práxis passa a depender do processo histórico real (e não mais do "homem real") que compõe a vida material da sociedade capitalista sem que o horizonte revolucionário implique sujeitar a realidade a um ideal comunista posterior, a "um estado que deve ser implantado". Pelo contrário, afirma-se que o comunismo só pode ser o "movimento efetivo que supera o estado de coisas atual. As condições deste movimento se desprendem do pressuposto atualmente vigente"24.

\footnotetext{
${ }^{21}$ Giannotti, op. cit., p. 61.

${ }^{22}$ Giannotti, op. cit., p. 183. Procurei analisar de maneira mais aprofundada a interpretação que Giannotti ofereceu a respeito deste desenvolvimento na obra de Marx em Melo (2011).

${ }^{23}$ Cf. Marx (1990a).

${ }^{24}$ Engels e Marx (1990, p. 35).
} 
Em cada modo de produção historicamente constituído encontramos simultaneamente o potencial emancipatório e os obstáculos à emancipação interpretados a partir da contradição entre "forças produtivas" e "relações de produção". Com a finalidade de superar a escassez, o homem age produtivamente. As forças produtivas se desenvolvem justamente para que as necessidades humanas possam ser satisfeitas. Em relações de produção simples (família ou mesmo tribo) contamos com baixo grau de produtividade. Mas quando os intercâmbios de troca se expandem para diferentes comunidades, aumentam as necessidades e, por conseguinte, a exigência de incremento das forças produtivas. Isso significa que cada contradição inerente a determinado modo de produção cria assim as condições para seu desenvolvimento histórico. Isso vale da escravidão para o feudalismo, deste para o capitalismo e, finalmente, do modo de produção capitalista para o comunismo. "E como essas condições correspondem em cada fase ao desenvolvimento simultâneo das forças produtivas", de acordo com Marx e Engels, "resulta que a história é, por seu turno, a história das forças de produção em desenvolvimento e herdadas por toda nova geração" 25 .

O capitalismo é marcado pelo radical aumento da produtividade (Revolução Industrial, desenvolvimento da técnica e da ciência). Porém, também é caracterizado pela apropriação privada das forças produtivas. Esta é uma contradição própria do modo de produção capitalista. Temos a possibilidade material e produtiva de finalmente superar de vez a escassez (mundialmente), já que as forças produtivas se desenvolveram em grau suficiente, mas esta satisfação universal das necessidades está bloqueada pelas relações de produção capitalistas, pelo recorte de classe a que a maior parte da população está submetida. Com a revolução proletária, e o posterior advento do comunismo, poderemos nos reapropriar coletivamente de todo o potencial já inerente à produtividade capitalista, deixando o "reino da necessidade" para entrar no "reino da liberdade".

Mesmo que neste contexto a perspectiva crítica esteja preocupada com a eclosão da luta de classes que decorreria do conflito entre forças produtivas e relações de produção, o horizonte emancipatório da teoria está concentrado no sistema produtivo enquanto tal. O principal consiste na radicalização do desenvolvimento das forças produtivas e na sua reapropriação. A luta de classes precisa revolucionar o entrave criado pela organização social das relações de produção, mas radicalizar, sem colocar em risco, os graus conquistados de produtividade no capitalismo. Pois, ao romper com os entraves à expansão das necessidades, da produção e das capacidades de autorrealização, o capitalismo criaria as condições materiais potenciais para a universalização das necessidades. A práxis revolucionária é travada agora em nome das legitimações presentes no próprio capitalismo no momento em que a aposta emancipatória é resultado inquestionável da universalidade e da satisfação do desenvolvimento das forças produtivas. Mas de que maneira a "autoemancipação" do proletariado assume papel constitutivo no processo produtivo do desenvolvimento material? O conceito de práxis social permanece reduzido à atividade produtiva, obscurecendo alternativas a um conceito de ação não determinado pelo paradigma da produção.

Além disso, em termos de fundamentação metodológica, o materialismo histórico acaba utilizando o conceito geral de modo de produção sem que as condições especificamente capitalistas façam parte de sua gênese categorial. Só poderíamos especificar diferentes sistemas produtivos na história porque a própria noção de uma "produção em geral" seria resultado não dos processos capitalistas, mas de abstração racional inferida pelo teórico ${ }^{26}$. Logo, o conceito de produção, na medida

\footnotetext{
${ }^{25}$ Idem, 1990, p. 72.

${ }^{26}$ Sobre a "produção em geral" e seu papel metodológico na crítica da economia política, cf. Marx (2005), Introdução. O problema apresentado nesta "Introdução" só será resolvido em O capital.
} 
em que assume aspectos críticos e redimensiona as atividades históricas em geral, aparece como uma solução ainda aberta para a relação entre teoria e práxis no quadro do materialismo histórico.

Apenas em sua obra máxima, O capital, Marx consegue finalmente retirar critérios críticos imanentes à lógica de desenvolvimento do próprio capitalismo, sem precisar lançar mão de um processo de abstração mental para distinguir e construir diferentes sistemas produtivos. Ao fazer a distinção entre reconstrução categorial e processo histórico, entre gênese lógica e gênese histórica ${ }^{27}$, Marx percebe que, na verdade, é a dialética específica do modo de produção capitalista - em que se definem processos de produção, distribuição e troca de mercadorias - que permite uma reconstrução genética de categorias abstratas essenciais e que constituem as atividades produtivas concretas. Em outros termos, o que caracteriza o modo de produção capitalista é o fato de seu sistema produtivo estar subordinado inteiramente às relações de troca de mercadorias fundadas no valor ${ }^{28}$. A constituição das relações concretas e dos critérios críticos imanentes decorre das categorias que definem em seu todo as atividades inerentes do próprio sistema e estruturam seu modo de produção. A partir de então, não há nada exógeno ao sistema de valorização do capital que lhe seja constitutivo. O que nos coloca a questão de entender o estatuto do horizonte crítico inscrito neste modelo de exposição peculiar e qual é a margem deixada para a dimensão da práxis.

Para ser imanente, o ponto de vista crítico oferecido em $O$ capital decorre necessariamente das contradições inerentes ao próprio processo de valorização. No limite, não basta mera vontade política, pois a emancipação resultaria da contradição engendrada somente de dentro do processo de produção determinado pelo capital. A crítica imanente deriva do diagnóstico sobre as contradições inerentes da forma capitalista e das possibilidades objetivas efetuadas pelo sistema. O Marx maduro foi capaz assim de compreender a natureza contraditória e sujeita a crises da totalidade social ${ }^{29}$. Nada foi tão brilhante em sua obra quanto esta exposição crítico-categorial. Entretanto, $O$ capital não diminuiria a dimensão constitutiva da práxis política e social na medida em que parece deduzir a lógica da luta de classes da própria lógica de reprodução capitalista e suas contradições imanentes? Como Marx evitaria neste livro que as crises e contradições ditassem a dinâmica da constituição e da transformação prática da história? Marx prioriza a análise sistêmica porque apenas suas contradições internas impediriam de fato o desdobramento lógico do capital.

Agora, o esquema estabelecido para mediar teoria e práxis dependeria necessariamente do diagnóstico do capitalismo, o qual assumiria a função de orientar de forma mais adequada a ação. Para tanto, o vínculo entre diagnóstico e orientação da ação está estreitamente ligado ao ponto de vista da contradição. Para uma práxis emancipatória eficaz, é preciso antes entender como, ao realizar-se de acordo com sua lógica de acumulação, o capital encontra dificuldades para continuar se valorizando. Em todo caso, não temos interferências exógenas imediatas no sistema, ou seja, não é uma lógica da política que poderá interromper objetivamente a reprodução do capital ${ }^{30}$. A possibilidade objetiva de dissolução do capital está nas leis de movimento do próprio capitalismo.

\footnotetext{
${ }^{27}$ Uma das mais importantes contribuições de Giannotti consiste em ter chamado atenção para esta distinção constitutiva. Cf. principalmente Giannotti, op. cit., p. 193-194.

${ }^{28}$ (Cf. MARX, 2005, cap. 1).

${ }^{29}$ Foi $O$ capital que motivou a discussão na esquerda a respeito da crise e do colapso do capitalismo. Sua mais famosa formulação se encontra na análise da "lei da queda tendencial da taxa de lucro". MARX, 2005, p. 222 et seq. Cf. Rohshausen (1970); Gillman (1969).

${ }^{30}$ Seria frutífero comparar o "modo de exposição" de O capital com aquele eminentemente político do Dezoito Brumário de Louis Bonaparte. Uma tentativa ainda inicial de comparação se encontra em Melo, op. cit., p. 158 et seq.
} 
Ora, após esta rápida reconstrução, terminamos diante de um problema clássico do marxismo e que será fonte de longo enfrentamento na tradição intelectual da teoria crítica. De que maneira recolocar o sujeito revolucionário ativo no quadro da exposição crítica obtida com O capital? Georg Lukács desafiou a explicação marxista da Revolução Russa ao se perguntar pelo sujeito da revolução, não mais limitado a considerar o "capital como sujeito", mas compreender como o proletariado faria sua própria história com consciência e vontade. A saída genial encontrada em História e consciência de classe consistiu em inventar a tão desejada junção entre Marx maduro e jovem Marx, mesclando a crítica imanente do capitalismo com a autonomia da práxis revolucionária que estaria presente nos textos de juventude ${ }^{31}$. Sabe-se que a solução de Lukács para a relação entre teoria e práxis dependeu de pressupostos igualmente fortes, a saber, de uma necessária articulação entre ciência materialista e consciência de classe que foi perdendo sua base empírica. E tal solução se manteve aberta assim que a "primeira geração" da teoria crítica, reunida em torno do Instituto de Pesquisa Social, buscou responder empiricamente em plena década de 1930 por que o proletariado alemão, após reunir as condições objetivas, não teria feito a revolução ${ }^{32}$.

Toda a crise da teoria da revolução trouxe à tona a dificuldade, desenrolada até os dias de hoje, de se fundamentar uma teoria crítica imanente vinculada com uma perspectiva prático-emancipatória em geral. Ou declaramos que a relação entre teoria e práxis está bloqueada ou a teoria passa a incorporar novos sujeitos sociais e políticos, alterando o pressuposto em que se encontrou apoiado por muito tempo o sentido emancipatório do marxismo revolucionário. O mais importante é que até hoje a questão perturba aqueles que pretendem fazer teoria crítica. Afinal, podemos ancorar o velho propósito emancipatório da teoria nos novos movimentos sociais? E a nova gramática dos conflitos sociais nas democracias contemporâneas não obriga a teoria crítica a ampliar os sentidos da emancipação em disputa? ${ }^{33}$ Todas as respostas dependem da produção renovada de diagnósticos do tempo presente. Mas acredito que o esforço de Marx nos ajuda a iluminar os desafios teóricos e práticos de nossa própria atualidade.

Correspondência: Rúrion Melo. Universidade de São Paulo - USP, Av. Prof. Luciano Gualberto, 315, 2 andar, sala 2047, Cidade Universitária, CEP 05508-900, São Paulo, SP, Brasil. E-mail: rurionmelo@gmail.com Conflito de interesses: Nenhum.

Todos os autores leram e aprovam a versão final submetida a revista Em curso.

\footnotetext{
${ }^{31}$ Cf. Lukács (1968). Cf. também Nobre (2001).

${ }^{32}$ Cf. Horkheimer (2009). Cf. também Jay (2008).

${ }^{33}$ Procurei desenvolver estas questões me debruçando sobre os novos modelos de teoria crítica em Melo (2013b); e Melo (2014).
} 


\section{Bibliografia}

BRUDNEY, D. Marx's Attempt to Leave Philosophy. Cambridge: Harvard University Press, 1998.

COHEN, J. Class and Civil Society: The Limits of Marxian Critical Theory. Amherst: University of Massachussets Press, 1982.

ENGELS, F.; MARX, K. Die heilige familie. In: ENGELS, F.; MARX, K. Marx-Engels Werke. Berlin: Dietz Verlag, 1957. v. 2.

FEUERBACH, L. A essência do cristianismo. Petrópolis: Vozes, 2007.

GIANNOTTI, J. A. Origens da dialética do trabalho. São Paulo: Difusão Europeia do Livro, 1966.

GILLMAN, J. Das Gesetz des tendenziellen Falls der Profitrate. Hamburg: Europäische Verlagsanstal, 1969.

HABERMAS, J. Entre filosofia e ciência: Marxismo como crítica. In: HABERMAS, J. Teoria e práxis. São Paulo: Unesp, 2013.

HARTMANN, K. Die Marxsche Theorie. Berlin: Walter de Gruyter, 1970.

HORKHEIMER, M. Traditionelle und kritische theorie. In: BENJAMIN, W. Gesammelte Schriften. Frankfurt: Fischer, 2009. v. 4.

JAY, M. A imaginação dialética: história da escola de Frankfurt e do Instituto de Pesquisas Sociais (1923-1950). Rio de Janeiro: Contraponto, 2008.

LÖWY, M. A teoria da revolução do jovem Marx. Petrópolis: Vozes, 2002.

LUKÁCS, G. Geschichte und Klassenbewu tsein. In: LUKÁCS, G. Georg Lukács Werke. Neuwied/Berlin: Luchterhand, 1968. v. 2. (Frühschriften II).

MARX, K. Aus der kritik der hegelschen rechtsphilosophie: kritik des hegelschen staatsrechts (§§ 261313). In: MARX, K. Marx-Engels Werke. Berlin: Dietz Verlag, 1961a. v. 1.

MARX, K. Zur judenfrage. In: MARX, K. Marx-Engels Werke. Berlin: Dietz Verlag, 1961b. v. 1.

MARX, K. Zur kritik der hegelschen rechtsphilosophie: einleitung. In: MARX, K. Marx-Engels Werke. Berlin: Dietz Verlag, 1961c. v. 1.

MARX, K. Thesen über Feuerbach. In: MARX, K. Marx-Engels Werke. Berlin: Dietz Verlag, 1990a. v. 40.

MARX, K. Ökonomisch-philosophishe Manuskripte (1844). In: MARX, K. Marx-Engels Werke. Berlin: Dietz Verlag, 1990b. v. 40.

MARX, K. Das Kapital. In: MARX, K. Marx-Engels Werke. Berlin: Dietz Verlag, 2005. v. 23-25.

MARX, K. Grundrisse der Kritik der politischen Ökonomie. In: MARX, K. Marx-Engels Werke. Berlin: Dietz Verlag, 2005. v. 42.

MELO, R. Crítica e contradição: qual herança marxista? Novos Estudos CEBRAP, São Paulo, v. 90, p. 21-32, 2011.

MELO, R. Marx e Habermas: teoria crítica e os sentidos da emancipação. São Paulo: Saraiva, 2013a.

MELO, R. Emancipação hoje e os desafios da democracia. Cadernos de Ética e Filosofia Política, São Paulo, v. 23, p. 6-19, 2013b.

MELO, R. Da teoria à práxis? Axel Honneth e as lutas por reconhecimento na teoria política contemporânea. Revista Brasileira de Ciência Política, Brasília, v. 15, p. 17-36, 2014.

MEYER, T. Der zwiespalt in der Marx'schen emanzipationstheorie. Kronberg: Scriptor Verlag, 1973.

NOBRE, M. Lukács e os limites da reificação: um estudo sobre história e consciência de classe. São Paulo: Editora 34, 2001.

ROHSHAUSEN, C. Kapitalismus und krise: eine kontroverse um das gesetz des tendenziellen falls der profitrate. Hamburg: Europäische Verlagsanstalt, 1970. 